Vasyliv N. Semchuk Ya.

\title{
INFLUENCE OF WELDING PROCESSES FOR UNDERGROUND PIPELINE REPAIR ON WELDER SAFETY
}

Об’єктом дослідження є безпека зварювальника при ремонті і будівнищтві підземних трубопроводів. Встановлено, що ручне електрозварювання характеризується значним впливом на організм людини, оскільки відстань від місия зварювання до зварника складає 20-30 см, температура в стовпі зварювальної дуги досягає 6500 К. Це сприяє виділенню у навколишній простір значної кількості металевої пари $і$ дрібнодисперсного пилу (зварювального аерозолю та токсичних газів). Проведені теоретичні і експериментальні дослідження початкової ділянки зварювального факелу (на висоті 0,4-0,5 м) при ручній, напівавтоматичній звариі в середовищі захисних газів $і$ звариі під шаром флюсу.

Запропоновані залежності для визначення осьових температур та швидкостей. Обтрунтовано, що поширення аерозолів при зварюванні трубопроводів в траншеї визначається фізичними процесами поширення зварювального факелу. Досліджено гігієнічні характеристики електродів типу АНО при зварювальних процесах. Встановлено, що валова кількість аерозолю в процесі зварювання електродами АНО-4 з фтористокальцієвим покриттям досягає 31 г/кг та токсичних речовин в аерозолі до 9 г/кг. Кількість газів

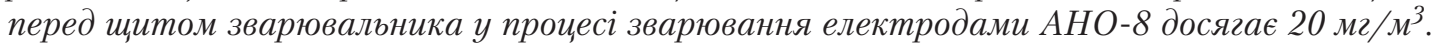

Одержані емпіричні рівняння для визначення конщентращї аерозолей та конщентрації газоподібних шкідливх речовин. Крім цього, одержано рівняння для визначення індексу забруднення робочих місць зварювальників, що дало можливість прогнозувати окремі параметри умов пращі.

Механізм поширення аерозолів у траншеї вимагає спещіального розгляду, що можна здійснювати методом математичного моделювання, оскільки тут відіграють роль такі фізико-хімічні прочеси, як повздовня та поперечна дисперсія, молекулярна дифузія.

Виконано аналіз емпіричних формул, які можна рекомендувати для визначення параметрів у початковій ділянці зварювального факела при стиковій зварці трубопроводу в траншеї.

ключові слова: безпека зварювальника, зварювальний факел, магістральні газопроводи, конвективне тепло, конщентрація аерозолю.

Received date: 05.06 .2019

Accepted date: 27.06.2019

Published date: 31.10 .2019
Copyright (C) 2019, Vasyliv N., Semchuk Ya. This is an open access article under the CC BY license (http://creativecommons.org/licenses/by/4.0)

\section{Introduction}

The main technological process in which a large amount of harmful emissions (nitric oxide, carbon monoxide, manganese oxide, fluoride compounds, ozone, dust and the heat associated with them) is released is welding.

Hygienic studies of welding processes include experimental and industrial studies. The experiment gives general data on the quantitative and qualitative composition of dust and gases, electromagnetic radiation, sound pressure level and the like. Industrial studies reveal the dynamics of these harmful factors during the day, week, season.

Welding of underground pipelines during their repair is carried out in a half-open space, and since the distance from the place of welding to the welder is only $20-30 \mathrm{~cm}$, there is a need to study the effect of welding processes when repairing underground pipelines on the safety of the welder.

The subject of the study is to increase the level of hygiene and safety during electrical welding during the repair of underground pipelines.

The theoretical and methodological basis of research is scientific works [1-3] in the direction of the effective- ness of managerial decisions on labor protection in the welding industry.

The main tasks of the work are the assessment of sanitary and hygienic working conditions, as well as studies of the allocation and spread of aerosols during the welding process.

In this regard, it is relevant to conduct research to reduce the risk of occupational diseases working by increasing the efficiency of welding production.

Thus, the object of research is the welder safety in the repair and construction of underground pipelines.

The aim of research is studying the effect of harmful substances on the human body when welding in half-open space (underground pipelines).

\section{Methods of research}

Experimental studies were conducted under production conditions. Welding work took place in the repair of in-depth gas pipelines and was carried out in trenches. In this case, welding processes occur with a rapid change in the temperature of the metal to be welded or cut. In a wide temperature range, various physical and chemical 
processes occur. All applied heat sources are characterized by high thermal power, contributes to the formation of a welding torch (or cutting jet).

For example, in electric arc welding, the temperature in the column of the welding arc reaches $6500 \mathrm{~K}$, and in the areas of the electrodes through which the welding current passes, it is close to the boiling point of the metal and reaches $2500-2600 \mathrm{~K}$. This contributes to the release of a significant amount of metal vapor into the surrounding space, which condenses, forming fine dust (welding spray). A number of toxic gases are also emitted [1,2].

The study of the laws of the welding torch is also the subject of work $[4,5]$. The mechanism of aerosol propagation in trenches requires special consideration, which can be carried out by mathematical modeling, since such physicochemical processes as longitudinal and transverse dispersion, molecular diffusion play a role here.

\section{Research results and discussion}

The burning of the welding arc is accompanied by a spray of drops of metal and slag from the weld pool, which is in the nature of microexplosions.

Convective heat, which is given by the arc and heated part to the surrounding air, causes the appearance of a rising contaminated stream - the welding torch (Fig. 1). Like any other convective flow, the welding torch consists of a booster (initial) and main sections.

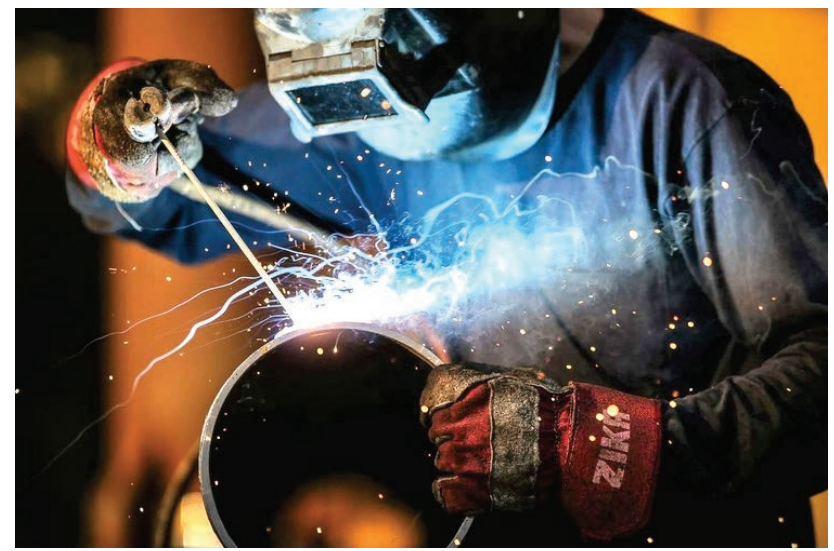

Fig. 1. Welding torch for manual electric welding with UONI-13 electrodes

In the accelerating section with a height of $0.3-0.4 \mathrm{~m}$, air leaks to the arc, heats up and rises, its velocity increases significantly. It is also clearly seen that the accelerating section of the welding torch has a smaller diameter than the main one, the convective flow is compressed by air, and leaks from the sides.

The main section of the welding torch is characterized by a decrease in axial velocities and temperatures as the torch rises and mixes it with the surrounding air. The experimental dependences for $v_{m}$ and $\Delta t_{m}$ in the case of manual welding with electrodes with a diameter of 3 and $5 \mathrm{~mm}$ are also shown in Fig. 2.

Processing the obtained data, taking into account the laws of thermal jets and the magnitude of convective heat $Q_{C}$, allowed the author of $[4,5]$ to conclude that the axial velocity (in $\mathrm{m} / \mathrm{s}$ ) and excess temperature $\Delta t_{m}$ (in ${ }^{\circ} \mathrm{C}$ ) in the main section of the welding torch are quite well described by theoretical dependences:

$$
\begin{aligned}
& v_{m}=0.136 \cdot Q_{C}^{1 / 3} \cdot \gamma^{-5 / 3}, \\
& \Delta t_{m}=0.5 \cdot Q_{C}^{1 / 3} \cdot \gamma^{-1 / 3},
\end{aligned}
$$

where $\gamma$ - distance along the vertical axis to a given point of the torch, $m$
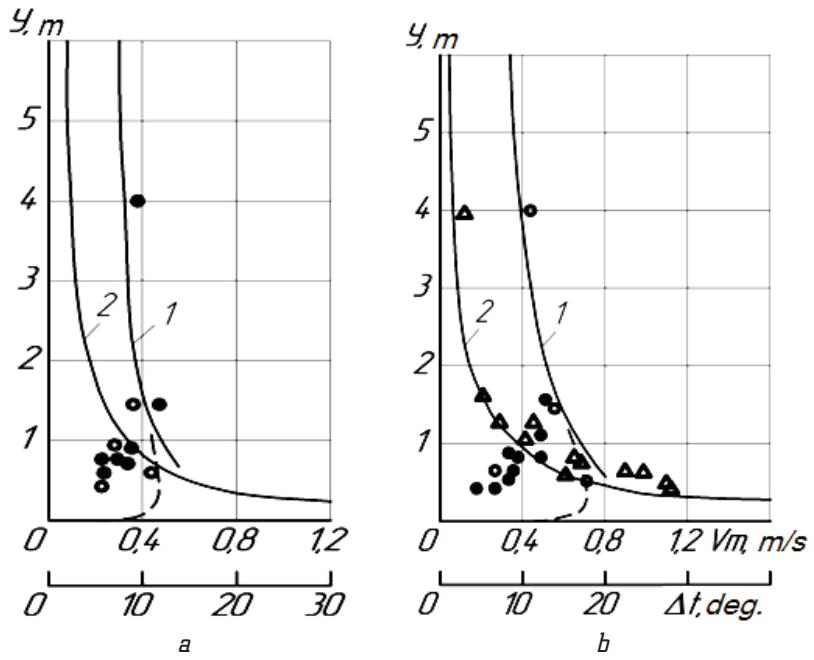

Fig. 2. The results of experimental studies of excessive temperatures and air velocities on the axis of the free welding torch: $a$ - parameters when welding with OMM-5 electrodes $\left(d=3 \mathrm{~mm}, I_{C B}=120 \mathrm{~A}\right)$; $b$ - parameters when welding with UONI-13 electrodes ( $d=5 \mathrm{~mm}_{i}$ $I_{C B}=250 \mathrm{~A}$ ); 1 - axial velocity; 2 - excess temperature

The distribution of axial relative concentrations and excess temperatures in the flare is subject to one dependence. Studies have also confirmed that with increasing arc power, the absolute values of the welding torch parameters increase. According to the indicated dependences, it is possible to calculate the values of axial velocities in the welding torch and the value of axial excess temperatures at a height $=0.4 \mathrm{~m}$ from the surface of parts and more.

As a result of theoretical and experimental studies of the initial section of the welding torch (at a height of $0.4-0.5 \mathrm{~m}$ ) during manual, semi-automatic and automatic welding in a shielding gas medium and welding under a flux layer, the following dependences are proposed to determine the maximum axial temperatures and velocities [4]:

- for manual and semi-automatic welding, $\mathrm{K}$ :

$\Delta t_{m}=k_{p} \cdot I_{D}^{0.222} \cdot \gamma^{-0.8}$

- for automatic welding, $\mathrm{K}$ :

$\Delta t_{m}=k_{a} \cdot\left(\lg I_{D}\right)^{0.071} \cdot \gamma^{-0.8}$

where $\gamma$ - height from the surface of the welded part to a given point, $\mathrm{m} ; I_{D}$ - welding current strength, A, when welding under a flux layer $k_{p}=6.5$ and $k_{a}=28$.

$$
v_{m}=\sqrt{g \cdot \gamma \cdot \frac{\Delta t_{m}}{T_{\infty}}},
$$

where $T_{\infty}-$ ambient temperature, which can be taken equal to $293 \mathrm{~K}$.

After substituting the digital values $\Delta t_{m}$ from formula (3), the formula for determining the axial velocity (in $\mathrm{m} / \mathrm{s}$ ) in 
the initial section of the welding torch (for manual welding), proposed in [6, 7], will look like:

$$
v_{m}=8 \cdot \sqrt{\frac{I_{D}^{0.222} \cdot \gamma^{0.2}}{T_{\infty}}}
$$

For example, when welding with $d=5 \mathrm{~mm}$ electrodes and a current of $250 \mathrm{~A}$, the air velocity is determined as follows: asking the mark of the welding torch, which interests us, for example, $\gamma=0.4 \mathrm{~m}$, at an ambient temperature of $20^{\circ} \mathrm{C}$ :

$$
v_{m}=8 \cdot \sqrt{\frac{250^{0.222} \cdot 0.4^{0.2}}{273+20}}=0.78 \mathrm{~m} / \mathrm{s} .
$$

Fig. 3 shows the data of experimental studies of the axial velocities of air in a welding torch during welding in $\mathrm{CO}_{2}$ with currents of 200,1200, and $3000 \mathrm{~A}$ [6]. Air velocity measurements were made by a special thermoelectric anemometer, the sensor of which had a thin platinum thread, and were not sensitive to the flux of radiant heat. Experimental points are the results of averaging multiple measurements of maximum velocities in each mode. As can be seen from the graphs of Fig. 3, the initial (accelerating) section in the welding torch has a height of $0.4-0.5 \mathrm{~m}$, the maximum air velocities are noted at a sample height of $0.3 \mathrm{~m}$ from the surface of the welded parts, that is, where the cross section of the torch is narrowed.

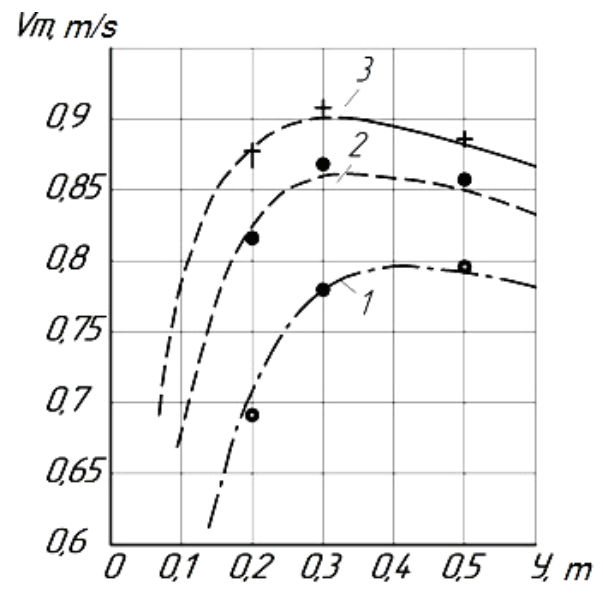

Fig. 3. Air velocities in the welding torch at current strength: 1 - $200 \mathrm{~A} ; 2-1200 \mathrm{~A} ; 3-3000 \mathrm{~A}$

The most important characteristic of the welding torch is the magnitude of convective heat $Q_{C}$, which determines the main parameters of convective flow. Various researchers in their works [7-9] recommend taking values of $Q_{C}$ that differ significantly from each other. It is found that for fast-moving welding arcs when welding with a consumable electrode with a diameter of $3 \mathrm{~mm} \quad Q_{C}=8-9 \%$, and for thick electrodes $Q_{C}=10-11 \%$ of the total thermal power of the arc $Q_{e q}$. When welding in $\mathrm{CO}_{2}$, the amount of convective heat in the welding torch increases and amounts to $12-14 \% Q_{e q}$. A significant part of the heat enters the welding torch not only from the surface of the parts, but also directly from the welding arc itself, and, with an increase in its power, the value $Q_{C}$ increases.
In the arc gap, intense heat is removed from the welding arc by forced convection due to the action of the cathode jet moving from the electrode to the workpiece at a velocity of about $100 \mathrm{~m} / \mathrm{s}$. Some heat enters the welding torch due to condensation of the metal vapor. A very important factor is the dissociation in the welding zone of a part of $\mathrm{CO}_{2}$ into $\mathrm{C}$ and $\mathrm{O}_{2}$ and further molization, which occurs in the welding torch with the release of heat.

All these processes with an increase in power consumption and an increase in temperature in the column of the welding arc are intensified, while the amount of convective heat provided is increased [10-12].

A number of empirical dependencies proposed by some researchers deserve attention. Studies [8] allows to obtain the following empirical formulas that can be recommended for determining the parameters in the initial section of the welding torch during butt welding:

- for convective flow velocity, $\mathrm{m} / \mathrm{s}$ :

$$
v_{m}=0.25 \cdot \sqrt[3]{\frac{N}{\gamma}}
$$

where $N$ - power spent in welding, kVA; $\gamma$ - distance from the welding point along the axis of the upward flow, m;

- for the volume moved by a stream of air, $\mathrm{m}^{3} / \mathrm{s}$ :

$$
L_{c}=0.012 \cdot \sqrt[3]{N \cdot \gamma^{5}}
$$

- for excess temperature on the axis of the flow, K:

$$
\Delta t_{m}=0.5 \cdot \sqrt[3]{\frac{N^{2}}{\gamma^{5}}} .
$$

In dependences (8) and (9) obtained by the author of [6], taking into account the well-known laws of compact convective flows, the power $N$ consumed during welding is introduced instead $Q_{c}$. The calculations of the torch parameters are done at values from 0.1 to $0.5 \mathrm{~m}$. For example, at a power of $10 \mathrm{kVA}$, the axial air velocity at a height of $0.5 \mathrm{~m}$ is $0.68 \mathrm{~m} / \mathrm{s}$. The obtained value is quite close to the values $v_{m}$, although the technological process differs significantly from welding with a consumable electrode.

Thus, it is substantiated in the work that the distribution of aerosols when welding pipelines in a trench is mainly determined by the physical processes of propagation of the welding torch. Based on this, the nature of the change in the concentration of welding aerosols in trenches with a pipeline is simulated.

\section{Conclusions}

It is shown that the distribution of aerosols during welding of underground pipelines in a trench is mainly determined by the physical processes of propagation of the welding torch. As a result of comprehensive studies, empirical dependencies are obtained to determine the concentration of gaseous harmful substances and to determine the pollution index of welders' jobs, which will make it 
possible to predict individual parameters of the working conditions of welders.

These research results will be useful for their implementation in production for the development of software for automatic control of the welding process to minimize harmful effects on the welder.

\section{References}

1. Hinds, W. C. (1999). Aerosol technology: properties, behavior, and measurement of aiborne particles. A Wiley-Interscience publication, 464

2. Vincent, J. H. (2007). Aerosol sampling: science, standarts, instrumentation and applications. Chichtster: John Wiley \& Sons Ltd, The Atrium, Southern Cate, 616. doi: http://doi.org/ 10.1002/9780470060230

3. Mandryk, O. M., Tyrlysh, V. V., Mykhailiuk, Yu. D. (2014). Determination of Multifactor Dependencies of Change of Exhaust Gases Composition in Different Modes of Gas Pumping Unit Operation. Scientific Bulletin Al Centrului Universitar Nord Din Baia Mare, XXIX (2), 71-83.

4. Elterman, V. M., Braude, M. Z. (1965). K voprosu modelirovaniia dvizheniia chastic v konvektivnom potoke vozdukha. Vodosnabzhenie $i$ sanitarnaia tekhnika, 1, 9-12.

5. Elterman, V. M. (1980). Ventiliaciia khimicheskikh proizvodsto. Moscow: Khimiia, 288

6. Pisarenko, V. L., Roginskii, M. L. (1981). Ventiliaciia robochikh mest v svarochnom proizvodstve. Moscow: Mashinostroenie, 120.

7. Polukarov, Yu. O. (2005). Modeliuvannia pylovoho navantazhennia na orhany dykhannia zvarnyka dlia otsinky ryzyku profesiinoi zakhvoriuvanosti. Kyiv, 140.
8. Levchenko, O. H., Bulat, A. V., Bezushko, O. M. (2009). Vplyv skladu osnovnoho metalu na hihiienichni kharakterystyky aerozoliv, shcho utvoriuiutsia pry zvariuvanni vysokolehovanykh stalei pokrytymy elektrodamy. Problemy okhorony pratsi v Ukraini, 17, 95-101.

9. Kurovets, Ya. V., Semchuk, Ya. M. (2011). Modeliuvannia poshyrennia aerozoliv $\mathrm{v}$ protsesi ruchnoho zvariuvannia pry remonti ta budivnytstvi liniinoi chastyny mahistralnykh truboprovodiv u polovykh umovakh. Rozvidka $i$ rozrobka naftovykh $i$ hazovykh rodovyshch, 4 (40), 57-62.

10. Levchenko, O. G. (1996). Processy obrazovaniia aerozolei. Avtomaticheskaia svarka, 4, 17-22.

11. Grudz, V. Ia., Tymkiv, D. F., Iakovlev, E. I. (1991). Obsluzhivaniia gazotransportnykh sistem. Kyiv, 160.

12. Taraevs'kyy, O. S. (2010). Maintaining the Reliable Operation of Oil and Gas Pipelines With Account for Mechanochemical Degradation. Technical sessions on welding. Madrid, $28-32$.

Vasyliv Nataliia, Department of Environmental Technologies and Labor Protection, Ivano-Frankivsk National Technical University of Oil and Gas, Ukraine, e-mail: natali160785@ukr.net, ORCID: http://orcid.org/0000-0002-1561-1141

Semchuk Yaroslav, Doctor of Technical Sciences, Professor, Department of Environmental Technologies and Labor Protection, Ivano-Frankivsk National Technical University of Oil and Gas, Ukraine,e-mail: bzhd@nung.edu.ua, ORCID: http://orcid.org/00000002-6189-2650 